\title{
Antitumor activity of the selective cyclooxygenase-2 inhibitor, celecoxib, on breast cancer in Vitro and in Vivo
}

\author{
Zhi-Jun Dai ${ }^{*}{ }^{\dagger}$ Xiao-Bin Ma ${ }^{\dagger}$, Hua-Feng Kang ${ }^{*}$, Jie Gao, Wei-Li Min, Hai-Tao Guan, Yan Diao, Wang-Feng Lu \\ and Xi-Jing Wang ${ }^{*}$
}

\begin{abstract}
Background: Cyclooxygenase-2(COX-2) promotes carcinogenesis, tumor proliferation, angiogenesis, prevention of apoptosis, and immunosuppression. Meanwhile, COX-2 over-expression has been associated with tumor behavior and prognosis in several cancers. This study investigated the antitumor effects of the selective COX-2 inhibitor, Celecoxib, on breast cancer in vitro and in vivo.

Methods: Human breast cancer MCF-7 and MDA-MB-231 cells were cultured with different concentration (10, 20, $40 \mu \mathrm{mol} / \mathrm{L}$ ) of celecoxib after 0-96 hours in vitro. MTT assay was used to determine the growth inhibition of breast cancer cells in vitro. The expression of COX-2 on mRNA was measured by real-time quantitive PCR analysis. Flow cytometry was performed to analyze the cell cycle of MCF-7 cells. Levels of PGE2 were measured by ELISA method. The in vivo therapeutic effects of celecoxib were determined using rat breast cancer chemically induced by 7,12-dimethylben anthracene (DMBA).

Results: The inhibition of proliferation of both MCF-7 and MDA-MB-231 cells in vitro by celecoxib was observerd in time and dose dependent manner. Celecoxib effectively down-regulated the expression of COX-2. The cell cycle was arrested at G0/G1, and rate of cells in S phase was obviously decreased. Levels of PGE2 were inhibited by Celecoxib. The tumor incidence rate of the celecoxib group was lower than that of the control group. In addition, the tumor latency period of the celecoxib group was longer than that of the control group.

Conclusions: Celecoxib inhibited the proliferation of breast cancer cell lines in vitro, and prevented the occurrence of rat breast cancer chemically induced by DMBA. Therefore, celecoxib exhibits an antitumor activity and seems to be effective in anti-tumor therapy.
\end{abstract}

Keywords: Breast cancer, Cyclooxygenase-2, Anti-tumor, DMBA

\section{Introduction}

Cyclooxygenases $(\mathrm{COX})$ exists in two isoforms, namely, COX-1 and COX-2. They are rate-limiting enzymes in the formation of prostaglandins from arachidonic acid. COX-1 is considered to be constitutively expressed, while COX-2 is highly inducible by various factors and is associated with tumorigenesis by enhancing angiogenesis $[1,2]$,

\footnotetext{
*Correspondence: dzj0911@126.com; kanghf73@yahoo.com.cn;

Wangxijing@21cn.com

${ }^{\dagger}$ Equal contributors

Department of Oncology, the Second Affiliated Hospital, Medical School of Xi'an Jiaotong University, Xi'an 710004, China
}

suppressing apoptosis [3], and promoting invasiveness as well as metastases [4].

COX-2 promotes carcinogenesis, tumor proliferation, angiogenesis, prevention of apoptosis, and immunosuppression [5]. COX-2 over-expression has been associated with tumor behavior and with prognosis in several cancers [6]. The selective inhibition of COX-2 activity in several animal models has been associated with a decrease of new blood vessel production in tumors, a decrease in new vessel formation, and an increase in tumor cell apoptosis [7]. Celecoxib is a paradigmatic selective inhibitor of COX-2. This anti-inflammatory drug has potent anti-tumor activity in a wide variety of human

\section{Biomed Central}

(C) 2012 Dai et al.; licensee BioMed Central Ltd. This is an Open Access article distributed under the terms of the Creative Commons Attribution License (http://creativecommons.org/licenses/by/2.0), which permits unrestricted use, distribution, and reproduction in any medium, provided the original work is properly cited. 
tumor types, such as colorectal, breast, and lung cancers [8-10].

The over-expression of COX-2 is associated with carcinogenesis, invasiveness, and with the metastasis of malignant tumors $[11,12]$. The roles of celecoxib in preventing and treating tumors have been attracting broad attention in recent years because of its selective and specific inhibition of COX-2 activity [13-16]. In this study, the inhibitory effect of celecoxib on the proliferation of the human breast carcinoma cell line MCF-7 was investigated in vitro and the breast cancer was chemically induced in vivo.

\section{Materials and methods Reagents}

MCF-7 cell was purchased from the Shanghai Institute of Cell Biology at the Chinese Academy of Sciences (Shanghai, P.R.China). RPMI1640 medium (Gibco, USA); Fetal bovine serum(Gibco, USA); 7,12-dimethylbenanthracene (DMBA), Dimethyl sulfoxide (DMSO), Propidiumiodide(PI) and 3(4,5- dimethylthiazol-2-yl) -2,5- diphenytetrazolium bromide (MTT) were purchased from Sigma Chemical (St. Louis, MO); Trizol (Invitrogen, USA);Celecoxib(Pfizer Pharmaceuticals Ltd, USA); Prostaglandin E2(PGE2) ELISA kit(Jingmei Biotech Co.,Ltd, China). Rats(Sprague-Dawley rats, female, age $45 \pm 5$ days, weighting $110 \pm 10 \mathrm{~g}$ ) were purchased from the Experiment Animal Center, Medical School of Xi'an Jiaotong University, Xi'an, China (Animal Certificate Number: No.08-005 of Shanxi medical animal test centre).

\section{Cell culture and cell proliferation assay}

Cells were cultured in RPMI-1640 medium(Gibco, USA) supplemented with $10 \%$ fetal bovine serum (Gibco, USA), $1 \times 10^{5} \mathrm{U} / \mathrm{L}$ penicillin and $100 \mathrm{mg} / \mathrm{L}$ streptomycin in a humidified atmosphere with $5 \% \mathrm{CO}_{2}$ incubator at $37^{\circ} \mathrm{C}$. The cells were subcultured until reaching logarithmic growth phase.

MTT assay was used to determine the effect of Celecoxib on the proliferation of MCF-7 cells. MCF-7 cells were seeded at a concentration of $5 \times 10^{3}$ cell /well in 96well plate, and grown at $37^{\circ} \mathrm{C}, 5 \% \mathrm{CO}_{2}$ incubator until adherence. After an overnight incubation in starvation medium containing $0.5 \%$ FBS, the cells on the culture plate were divided into groups on the basis of parallel lines, each group had four wells in one line for each group. At the end of the treatment, $20 \mu \mathrm{l} \mathrm{MTT}(5 \mathrm{mg} / \mathrm{ml})$ was added and the cells were incubated for another 4 hours. $200 \mu \mathrm{l}$ of DMSO was added to each well after removing the supernatant. After shaking the plate for 10 mins. in the shaking board, cell viability was obtained by measuring the absorbance at $490 \mathrm{~nm}$ wavelength using Enzymelabeling instrument (Bio-Tek ELX800, USA), this assay was done triplicate. The inhibition rate was calculated using the following formula [17]:

Inhibition rate $(\%)=[1$-(average absorbance of experimental group/average absorbance of blank control group)] $\times 100 \%$.

\section{Real-time quantitative RT-polymerase chain reaction assay for COX-2 expression}

MCF-7 cells were seeded in 6-well plates and treated with concentration gradient Celecoxib $(0,10,20,40 \mu \mathrm{mol} / \mathrm{L}) \mathrm{se}-$ parately for 0-96 h. As previously described [18], cells collected at specified time were used to extract total RNA using the Trizol reagent following the manufacturer's instructions. RNA was reverse-transcribed into cDNA using a Primescript ${ }^{\mathrm{TM}}$ RT reagent kit according to the manufacturer's instructions. Real-time quantitative polymerase chain reaction (PCR) was carried out with the SYBR Green fluorescent dye method, and a Rotor Gene 3000 real-time PCR apparatus. COX-2 primer sequence (Invitrogen $\mathrm{CO}$ ): 5'- ATCCTTGCTGTTCCCACCA-3' (sense) and 5'-CTT TGACACCCAAGGGAGT- $3^{\prime}$ (anti-sense). $\beta$-actin, its primer sequence was $5^{\prime}$-GTTGCGTTACACCCTTTCTTG-3' (sense), 5'-TGCTGTCACCTTCACC GTTC-3' (antisense). $\beta$-actin was used as an internal control to evaluate the relative expressions of COX-2. The PCR conditions were as follows: a pre-denaturing at $95^{\circ} \mathrm{C}$ for $2 \mathrm{~min}$, followed by 45 cycles of denaturation at $95^{\circ} \mathrm{C}$ for $10 \mathrm{~s}$, annealing/extension at $60^{\circ} \mathrm{C}$ for $20 \mathrm{~s}$. The amplification specificity was checked by melting curve analysis. The PCR products were visualized by gel electrophoresis to confirm the presence of a single product with a correct size. The $2^{-{ }^{\Delta \Delta C T}}$ method was used to calculate the relative abundance of target gene expression generated by RotorGene Real-Time Analysis Software 6.1.81. For each cDNA, the target gene mRNA level was normalized to $\beta$-actin mRNA level. The experiments were performed for three times.

\section{Determination of PGE2 synthesis}

As previously described [19], MCF-7 Cells were grown in 12-well plates overnight. 30 min before harvesting of culture media, the culture media of the cells were changed to new media, and then these culture media were centrifuged to remove cell debris. Cell-free culture media were collected at indicated times and PGE2 levels were determined by competitive enzyme-linked immunosorbent assay (ELISA) as described by the kit manufacturer (Cayman Chemical, Ann Arbor, MI, USA) using an ELISA reader ( $\mu$ Quant; Biotek Instruments, Inc, Winooski, VT, USA).

\section{Cell cycle analysis by FCM}

MCF-7 cells were incubated at $5 \times 105$ cells/well in 6-well plates, treated with a homologous drug for $48 \mathrm{~h}$. The detached and attached cells were harvested and 
fxed in $70 \%$ ice-cold ethanol at $-20^{\circ} \mathrm{C}$ overnight. After fixation, cells were washed with PBS, resuspended in $1 \mathrm{~mL}$ PBS containing $1 \mathrm{mg} / \mathrm{mL}$ RNase (Sigma) and $50 \mu \mathrm{g} / \mathrm{mL}$ PI (Sigma), and incubated at $37^{\circ} \mathrm{C}$ for 30 min in the dark. Samples of 10000 cells were then analyzed for DNA content by FACScan flow cytometry (Beckman, USA), and cell cycle phase distributions were analyzed with the CellQuest acquisition software (BD Biosciences).

\section{Antitumor activity in vivo}

All the animals were maintained under standard environmental conditions and provided with food and water ad libitum. All the animals were fed with a normal pellet diet one week prior to the experimentation.

Female Sprague-Dawley rats were gavaged with 60 mg of DMBA/kg body weight, which was sufficient to cause $100 \%$ tumor incidence in the rats over the course of the study, as described by Whitsett et al. [20]. The DMBA was dissolved in olive oil at a stock solution of $30 \mathrm{mg} / \mathrm{ml}$.

After modeling, 90 rats were randomly divided into three groups, namely, the control group(normal diet after modeling), which was considered as the negative control, the positive control (tamoxifen) group $(4 \mathrm{mg} / \mathrm{kg}$ of tamoxifen was put in drinking water), and celecoxib group (solved in the oleum maydis, $1000 \mathrm{mg} / \mathrm{kg}$ of celecoxib was put in forage). The breasts of the rats were assessed twice a week, when palpable breast neoplasm appeared. The number of breast neoplasms and their changes in size were recorded.

After 120 days, the experiment was stopped. A vaginal smear examination was performed to confirm that the rats were in the dioestrus period. The rats were anesthetized by an intraperitoneal injection of $5 \%$ urethane. Then, every mammary gland with surrounding skin and hypodermia were dissected.The mammary glands were cut half open to observe the tumor shape and to count the number of tumors. The size of the tumors was measured using a $1 \mathrm{~mm}$ precision sliding caliper. The tumor incidence rate of each group was calculated. The tumor volumes was calculated according to the following equation: length $\times$ weight $\times$ height $\times \pi / 6$ [21]. If one rat had many tumors, the volume of this rat was the sum of all its tumors.

The specimens were fixed in 10\% neutral formalin, embedded in paraffin and stained with hematoxylineosin for the histological examination. The diagnosis of rat breast cancer was performed according to the diagnostic code of experimental rat breast cancer [22].

\section{Statistical analysis}

All values were expressed as the mean \pm standard deviations (SD). Statistical analysis was performed with one- way analysis of variance (ANOVA) and student $t$ test using the statistical software SPSS 13.0. $P<0.05$ was considered as statistically significant.

\section{Results and discussions}

Celecoxib inhibited the proliferation of breast cancer cells in vitro

The anti-proliferative effect of celecoxib on two breast cancer cell lines, MCF-7 cells (ER - positive) and MDA-MB231 (ER-negative), were examined using MTT assays. Cells were treated with medium and different doses of celecoxib, and the inhibition rate was evaluated after $0 \mathrm{~h}$ to $96 \mathrm{~h}$. Celecoxib in the high dose and medium dose groups could significantly inhibit the proliferation of both MCF-7 cells and MDA-MB-231 cells. As shown in Figure 1, the inhibitory rates of celecoxib on cell growth were $(62.6 \pm 4.5) \%$, $(67.5 \pm 4.8) \%,(78.7 \pm 6.3) \%$ in MCF-7 cells, and $53.5 \pm 3.7) \%$, $(62.3 \pm 4.5) \%,(70.9 \pm 7.1) \%$ in MDA-MB-231 cells, when the cells were treated with different doses of celecoxib for 96 hours. Thus, Celecoxib inhibited breast cancer cell proliferation in a dose- and time-dependent manner.

Celecoxib is known to induce apoptosis [23], but its effect on proliferative is not conclusive. For example, some researches reported that celecoxib did not affect tumor cell proliferation in primary adenocarcinomas and ductal carcinoma in situ of the breast in vivo $[24,25]$. However, celecoxib could prevent the development of breast cancer with ER-negative and HER-2-positive status [26]. These results indicate that the effect on proliferative of celecoxib is related with tumor's molecular phenotype possibly. In this study, we choose a ER -positive breast cancer cell line (MCF-7) and a ER -negative breast cancer cell line (MDA-MB-231), and found celecoxib could significantly inhibit the proliferation of both MCF-7 cells and MDA-MB-231 cells in a dose- and timedependent manner.

\section{COX-2 mRNA expression detected by real-time qPCR}

Real-time qPCR assay was used for COX-2 mRNA expression. It revealed that COX-2 mRNA was highly expressed in normal breast cancer cells. What's more, as celecoxib concentration increased, the mRNA expression of COX-2 gradually decreased. As shown in Figure 2, the amount of COX-2 mRNA in both MCF-7 cells and MDA-MB-231 cells after celecoxib treatment were significantly decreased in a dose-dependent manner.

It was previously reported that COX-2 is expressed in most human cancers including those of the breast, and administration of selective COX-2 inhibitors in humans may reduce the risk of cancer development [27]. Our date indicated that cell viability was gradually declined as celecoxib concentration increased. As can been seen, the lowest COX-2 mRNA was in $40 \mu \mathrm{mol} / \mathrm{L}$ group. Therefore, celecoxib could suppress expression of COX-2 to 

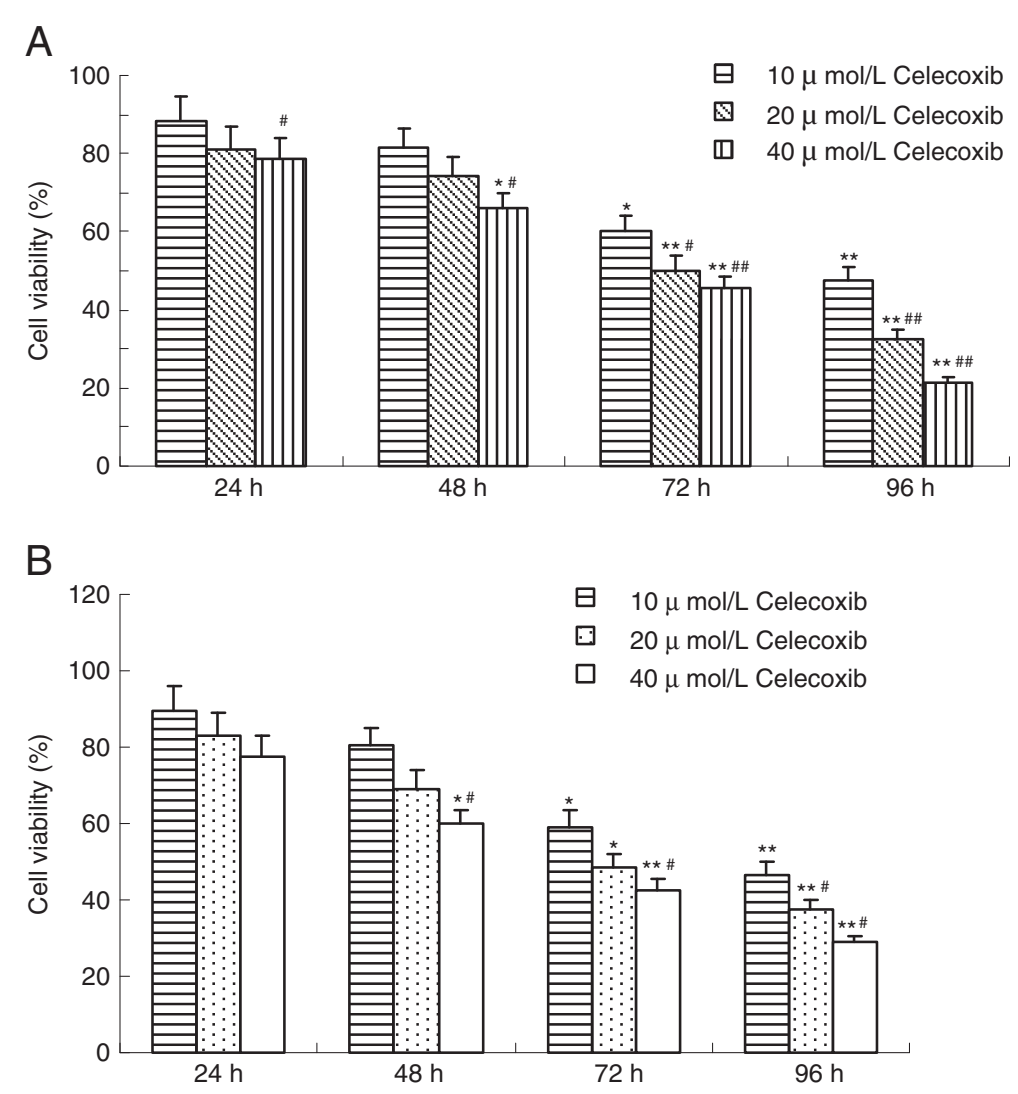

Figure 1 Growth inhibiting effects of Celecoxib in MCF-7 cells (A) and MDA-MB-231 cells (B). Cell viability was determined by MTT method. This assay was performed in triplicate. Dose- and time-dependent inhibition of cell growth could be observed after $96 \mathrm{~h}(P<0.05$, ANOVA analysis). ${ }^{*} P<0.05,{ }^{*} P<0.01$ vs. $24 \mathrm{~h} ;{ }^{\#} P<0.05,{ }^{\# \#} P<0.01 \mathrm{vs.10} \mu \mathrm{mol} / \mathrm{L}$ celecoxib.

inhibit cell proliferation. This results points out the efficacy of celecoxib against breast cancer growth.

\section{Effects of celecoxib on the PGE2 level of MCF-7 cells by ELISA}

Prostaglandin E2 (PGE2) is an important mediator in tumor-promoting inflammation [28]. The major mechanism of COX-2 in stimulating tumorigenesis is its product, PGE2. PGE2 promotes tumor cell proliferation, induces VEGF up-regulating, and inhibits tumor cell apoptosis as well as immune function [29]. Tari et al. [30] reported that COX-2 induced PGE2 to stimulate the activities of protein kinases $\mathrm{A}$ and $\mathrm{C}$ and induced tamoxifen resistance in $\mathrm{ER}$ alpha-positive breast cancer cells selectively. However, the COX-2 selective inhibitor celecoxib can inhibit tumorigenesis and tumor development through these ways.

In this study, the PGE2 level of MCF-7 cells was determined with ELISA analysis. As shown in Figure 3, the PGE2 level of MCF-7 cells in the control group and in the $10 \mu \mathrm{mol} / \mathrm{L}$ to $40 \mu \mathrm{mol} / \mathrm{L}$ celecoxib groups were $(75.32$ $\pm 8.73),(58.15 \pm 6.56),(42.84 \pm 6.12)$ and $(28.65 \pm 4.33) \mathrm{pg} / \mathrm{mL}$, respectively. PGE2 levels in the celecoxib therapy groups were significantly lower than that in the control group.
Furthermore, the PGE2 level gradually decreased in a dose-dependent manner $(P<0.01)$.

\section{Effects of celecoxib on the cell cycle distribution by flow cytometry}

Celecoxib may exert an inhibitory effect on the enhanced radiation-induced G2/M arrest in the COX-2overexpressing cells. This effect may allow the arrested cells to enter mitosis and die after radiation [31]. It has been found that a low dose of celecoxib $(5 \mu \mathrm{M}$ to $10 \mu \mathrm{M})$ could induce G2/M arrest, followed by the induction of apoptosis in the transformed cells but not in the normal cells. Growth inhibition was related to the COX-2 function with $90 \%$ to $95 \%$ reduction in PGE2 production [32]. However, Liu et al. [33] holds a different opinion that celecoxib can induce apoptosis and cell-cycle arrest at the G0/G1 checkpoint in the nasopharyngeal carcinoma cell lines, which is associated with a significantly reduced STAT3 phosphorylation.

In the present study, the effects of celecoxib on cell cycles were analyzed using flow cytometry. The percentage of cells in the celecoxib therapy groups significantly 


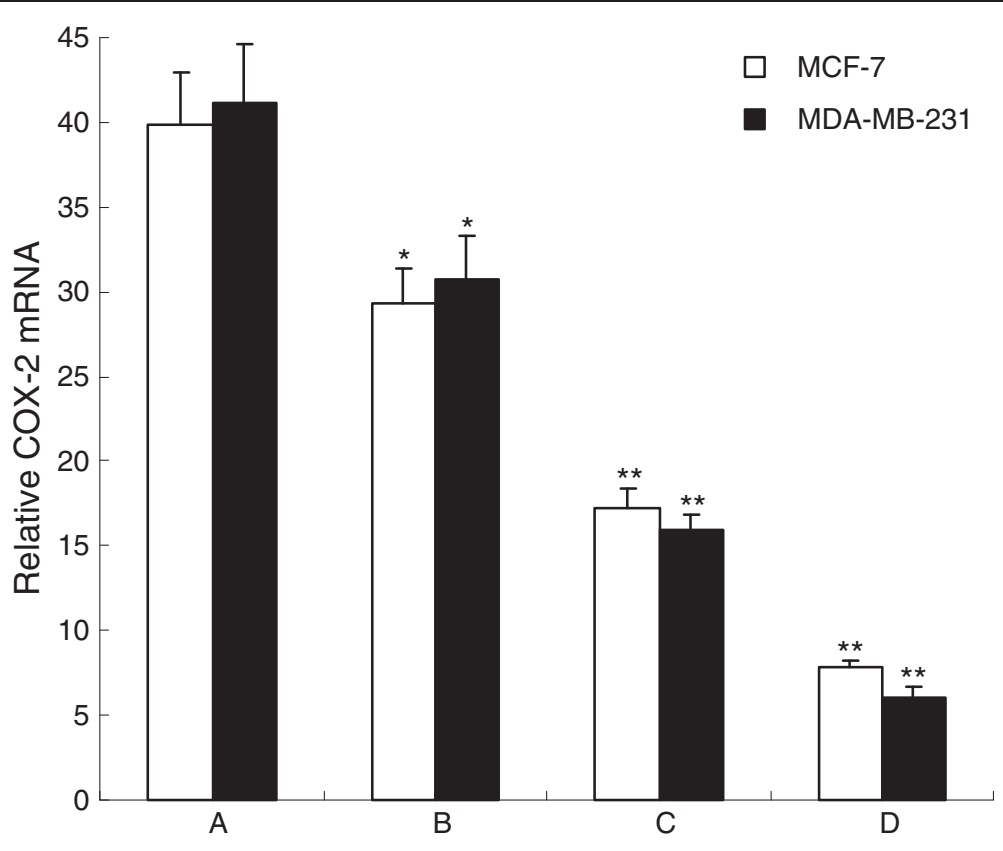

Figure 2 Effect of Celecoxib on expression of COX-2 mRNA of MCF-7 cells by real-time qPCR analysis. A: Control group; B: $10 \mu \mathrm{mol} / \mathrm{L}$ Celecoxib; C: $20 \mu \mathrm{mol} / \mathrm{L}$ Celecoxib; D: $40 \mu \mathrm{mol} / \mathrm{L}$ Celecoxib. The expression of COX-2 mRNA in MCF-7 cells were determined by real-time qPCR after treated with 0-40 $\mu \mathrm{mol} / \mathrm{L}$ celecoxib for $48 \mathrm{~h}$. This assay was done triplicate. Values represent means \pm standard deviations and were determined using the Student's $t$-test. ${ }^{*} P<0.05$, ${ }^{* *} P<0.01$ vs. control.

decreased at the $S$ phase and increased at the G0/G1 phase. These results suggest that celecoxib can induce cell cycle arrest at the G0/G1 phase in MCF-7 cells (Figure 4). Besides, the cells at the G2/M phase significantly decreased in the $40 \mu \mathrm{mol} / \mathrm{L}$ celecoxib group compared with that in the control group.

\section{Anti-tumor effects of celecoxib on DMBA-induced breast cancer}

Celecoxib has a striking chemopreventive activity. It can inhibit preneoplastic lesions during hepatocarcinogenesis in vivo, which suggests that celecoxib effects are mediated by PGE2-independent mechanisms [34]. A low

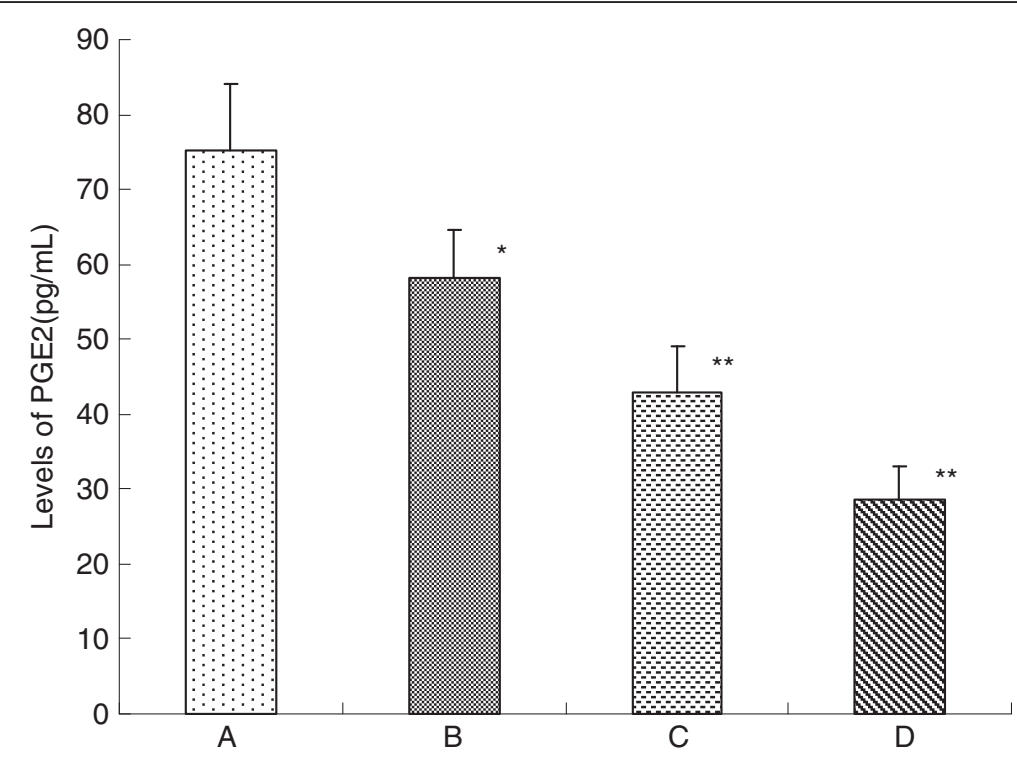

Figure 3 Effects of celecoxib on the PGE2 level of MCF-7 cells by ELISA. A: control group; B: $10 \mu \mathrm{mol} / \mathrm{L}$ celecoxib; C: $20 \mu \mathrm{mol} / \mathrm{L}$ celecoxib; D: $40 \mu \mathrm{mol} / \mathrm{L}$ celecoxib. PGE2 levels of MCF-7 cells were determined by ELISA after treated with $0-40 \mu \mathrm{mol} / \mathrm{L}$ celecoxib for $48 \mathrm{~h}$. This assay was done triplicate. Values represent means \pm standard deviations and were determined using the Student's $t$-test. ${ }^{*} P<0.05$, ${ }^{* *} P<0.01$ vs. control. 


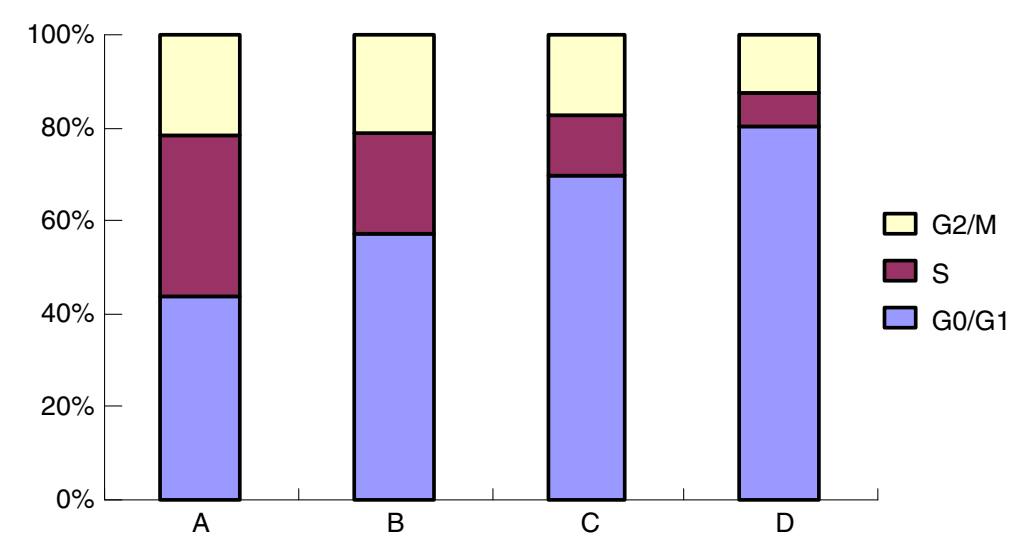

Figure 4 Effects of celecoxib on the cell cycle of MCF-7 cells by flow cytometry. A: control group; B: $10 \mu m o l / L$ celecoxib; C: $20 \mu m o l / L$ celecoxib; D: $40 \mu \mathrm{mol} / \mathrm{L}$ celecoxib. The cell cycle distributions in MCF-7 cells were determined by PI staining and flow cytometric analysis after treated with 0-40 $\mu \mathrm{mol} / \mathrm{L}$ celecoxib for $48 \mathrm{~h}$. Results presented were representative of three independent experiments.

dose of celecoxib can augment CDDP-induced growth inhibition of Tca8113 cells and its xenograft in Balb/c nude mice [35]. It is reported by Nakatsug et al. [21] that $400 \mathrm{ppm}$ of nimesulide could degrade tumor incidence rate, volume and multisitus rate. This study found that celecoxib could inhibit rat carcinogenesis and cancer development. With a dosage of $1000 \mathrm{ppm}$, celecoxib decreased the incidence rate, average tumor number and tumor volume with statistical significance $(P<0.05)$, compared with that of tumor control group. As in vitro, celecoxib inhibited MCF-7 cell proliferation in a dose- and time-dependent manner, while in vivo, celecoxib could inhibit rat carcinogenesis and cancer development in a dose-dependent manner. Abou Issa et al. [9] observed the preventive effect of celecoxib on 7,12-dimethylben anthracene (DMBA)-induced rat breast cancer. When treated with $250 \mathrm{ppm}, 500 \mathrm{ppm}, 1000 \mathrm{ppm}$ and $1500 \mathrm{ppm}$ celecoxib, the incidence rate was $80 \%, 50 \%, 45 \%$ and $25 \%$ respectively, compared with that of $100 \%$ incidence rate in control group $(P<0.001)$.

In the present study, celecoxib was found to be capable of inhibiting rat carcinogenesis and cancer development. The tumor incidence rate of each group was $85.71 \%(24 / 28)$ in the control group, $50.00 \%(14 / 28)$ in the celecoxib group, and $48.15 \%(13 / 27)$ in the tamoxifen group. As shown in Figure 5, the tumor latency period of the celecoxib group was significantly longer than that of the control group $(P<0.05)$. In addition, no significant difference was found between the celecoxib and tamoxifen groups $(P>0.05)$.

The average tumor numbers of each group were as follows: $3.50 \pm 1.62(1-7)$ pieces in the control group; $1.77 \pm 0.73$ (1-3)pieces in the tamoxifen group; and $1.71 \pm 0.61(1-2)$ pieces in the celecoxib group. The average tumor numbers of the celecoxib and tamoxifen groups were less than that

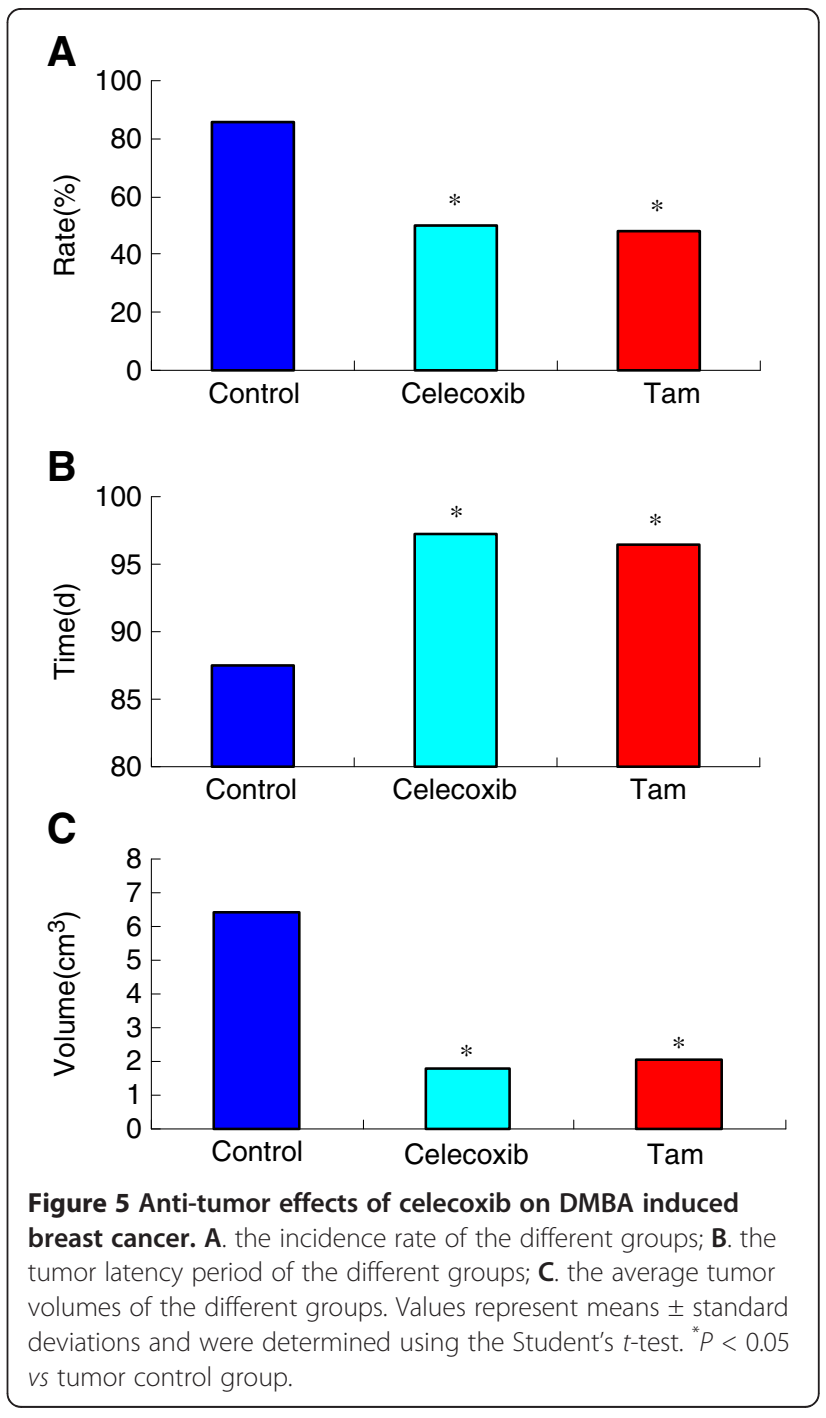




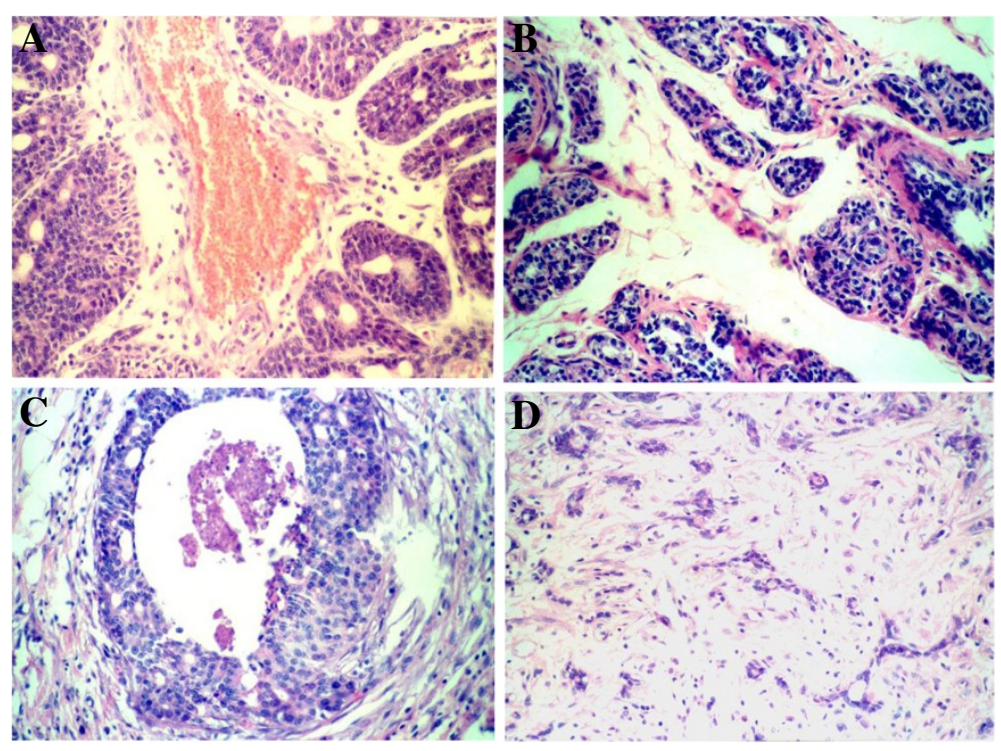

Figure 6 Breast sections of the different groups. A. Infiltrating ductal cancer in control group; B. Atypical hyperplasia in control group; C. Infiltrating ductal cancer in celecoxib group; D. Hyperplasia in celecoxib group (HEX200).

of the control group $(P<0.05)$. No significant difference was found between the two treatment groups $(P>0.05)$.

The average tumor volumes of each group were $6.42 \pm 3.96 \mathrm{~cm}^{3}$ in the control group, $1.78 \pm 0.71 \mathrm{~cm}^{3}$ in the tamoxifen group, and $2.05 \pm 1.04 \mathrm{~cm}^{3}$ in the celecoxib group. No significant difference was found between the tumor volumes of the celecoxib and tamoxifen groups $(P>0.05)$. The tumor volumes of the two treatment groups decreased significantly compared with the tumor control groups $(P<0.05)$.

\section{Histopathological observation}

The tissues of the control group presented an infiltrating ductal carcinoma, showing cancer nest, obvious nuclear atypia and nuclear division. A few gland-like structures and stroma were also observed (Figure 6A). The medullary carcinoma was composed of cancer cells and had ductless glands. The specimens without tumorigenesis showed different degrees of lobuli mammae hyperplasia and glandular epithelium atypical hyperplasia. The slight degree of hyperplasia showed an expanded or increased intralobulus and interlobulus fibrous tissue and gland alveolus. However, acinous cells were still in the monolayer. The atypical hyperplasia showed acinous cells that were arranged disorderly and in a multilayer, an increased karyoplasmic ratio, and changed nuclear atypia (Figure 6B).

In the experimental groups, the infitrating ductal carcinoma had more gland-like structures and stroma wherein the cells were dispersed. A few nuclear atypia and nuclear division were also observed (Figure 6C). The specimens that did not cancerate showed no or a slight degree of glandular epithelium hyperplasia, increased intralobulus and interlobulus fibrous tissue, and lesser gland alveolus and ducts (Figure 6D).

\section{Conclusions}

In conclusion, celecoxib inhibited the proliferation of breast cancer cell lines in vitro. Furthermore, the inhibitory effect of celecoxib on the proliferation of breast cancer cells in vitro was observed in a dose- and timedependent manner. The cell cycle was arrested at G0/ G1, and the rate of cells in the S phase was obviously decreased. In addition, celecoxib could prevent the occurrence of rat breast cancer in vivo. Therefore, celecoxib exhibits an antitumor activity and seems to be effective in anti-tumor therapy. However, further studies are needed to clarify the detailed mechanism involved in the antitumor effects of celecoxib.

\section{Competing interest}

The authors declare that there are no conflicts of interest in relation to this article.

\section{Authors' contributions}

DZJ and WXJ designed the research. DZJ, MXB, GJ, MWL and DY performed the experiments throughout this research. LXX, KHF and GHT contributed to the reagents, and participated in its design and coordination. DZJ and GJ analyzed the data; DZJ and MXB wrote the paper. Co-first authors: DZJ and MXB. All authors have read and approved the final manuscript.

\section{Acknowledgements}

This study was supported by the Fundamental Research Funds for the Central Universities, China; Tackle Key Problems in Science and Technology Foundation of Shaanxi Province, China [NO. 2011K13-03-08]. The funding sources had no role in the study design, data collection, analysis and interpretation, or in the writing of this manuscript.

Received: 5 September 2012 Accepted: 18 December 2012

Published: 19 December 2012 


\section{References}

1. Tsujii M, Kawano S, Tsuji S, Sawaoka H, Hori M, Dubois RN: Cyclooxygenase regulates angiogenesis induced by colon cancer cells. Cell 1998, 93:705-716.

2. Gately S: The contributions of cyclooxygenase-2 to tumor angiogenesis. Cancer Metastasis Rev 2000, 19:19-27.

3. Sheng H, Shao J, Morrow JD, Beauchamp RD, Dubois RN: Modulation of apoptosis and $\mathrm{BCl}-2$ expression by prostaglandin E2 in human colon cancer cells. Cancer Res 1998, 58:362-366.

4. Tsujii M, Kawano S, DuBois RN: Cyclooxygenase-2 expression in human colon cancer cells increases metastatic potential. Proc Natl Acad Sci USA 1997, 94:3336-3340.

5. Koki AT, Masferrer JL: Celecoxib: a specific COX-2 inhibitor with anticancer properties. Cancer Control 2002, 9:28-35.

6. Choy $H$, Milas L: Enhancing radiotherapy with cyclooxygenase-2 enzyme inhibitors: a rational advance? J Natl Cancer Inst 2003, 95:1440-1452.

7. Kobayashi H, Gonda T, Uetake H, Higuchi T, Enomoto M, Sugihara K: JTE-522, a selective COX-2 inhibitor, interferes with the growth of lung metastases from colorectal cancer in rats due to inhibition of neovascularization: a vascular cast model study. Int J Cancer 2004, 112:920-926.

8. Lou J, Fatima N, Xiao Z, Stauffer S, Smythers G, Greenwald P, Ali IU: Proteomic profiling identifies cyclooxygenase-2-independent global proteomic changes by celecoxib in colorectal cancer cells. Cancer Epidemiol Biomarkers Prev. 2006, 15:1598-1606.

9. Abou-lssa HM, Alshafie GA, Seibert K, Koki AT, Masferrer JL, Harris RE: Dose-response effects of the COX-2 inhibitor, celecoxib, on the chemoprevention of mammary carcinogenesis. Anticancer Res 2001, 21:3425-3432.

10. Park W, Oh TY, Han JH, Pyo H: Antitumor enhancement of celecoxib, a selective Cyclooxygenase-2 inhibitor, in a Lewis lung carcinoma expressing Cyclooxygenase-2. J Exp Clin Cancer Res 2008, 27:66-74.

11. Müller-Decker K, Fürstenberger G: The cyclooxygenase-2-mediated prostaglandin signaling is causally related to epithelial carcinogenesis. Mol Carcinog 2007, 46:705-710

12. Grösch S, Maier TJ, Schiffmann S, Geisslinger G: Cyclooxygenase-2 (COX-2)independent anticarcinogenic effects of selective COX-2 inhibitors. J Nat/ Cancer Inst 2006, 98:736-747.

13. Reddy BS, Hirose Y, Lubet R, Steele V, Kelloff G, Paulson S, Seibert K, Rao CV: Chemoprevention of colon cancer by specific cyclooxygenase-2 inhibitor, celecoxib, administered during different stages of carcinogenesis. Cancer Res 2000, 60:293-297.

14. Jang TJ, Jung HG, Jung KH, O MK: Chemopreventive effect of celecoxib and expression of cyclooxygenase- 1 and cyclooxygenase- 2 on chemically-induced rat mammary tumours. Int J Exp Pathol 2002, 83:173-182.

15. Keller JJ, Giardiello FM: Chemoprevention strategies using NSAIDs and COX-2 inhibitors. Cancer Biol Ther 2003, 2:1-9.

16. Hilmi I, Goh KL: Chemoprevention of colorectal cancer with nonsteroidal anti-inflammatory drugs. Chin J Dig Dis 2006, 7:1-6.

17. Dai ZJ, Gao J, Li ZF, Ji ZZ, Kang HF, Guan HT, Diao Y, Wang BF, Wang XJ: In Vitro and In Vivo Antitumor Activity of Scutellaria barbate Extract on Murine Liver Cancer. Molecules 2011, 16:4389-4400.

18. Zhang JQ, Li YM, Liu T, He WT, Chen YT, Chen XH, Li X, Zhou WC, Yi JF, Ren ZJ: Antitumor effect of matrine in human hepatoma $\mathrm{G} 2$ cells by inducing apoptosis and autophagy. World J Gastroenterol 2010, 16:4281-4290.

19. Tai $\mathrm{MH}$, Weng $\mathrm{CH}$, Mon DP, Hu CY, Wu MH: Ultraviolet CIrradiation Induces Different Expression of Cyclooxygenase 2 in NIH 3T3 Cells and A431 Cells: The Roles of COX-2 Are Different in Various Cell Lines. Int J Mol Sci 2012, 13:4351-4366.

20. Whitsett T, Carpenter M, Lamartiniere CA: Resveratrol, but not EGCG, in the diet suppresses DMBA-induced mammary cancer in rats. J Carcinog 2006, 5:15.

21. Nakatsugi S, Ohta T, Kawamori T, Mutoh M, Tanigawa T, Watanabe K Sugie S, Sugimura T, Wakabayashi K: Chemoprevention by nimesulide, a selective cyclooxygenase-2 inhibitor, of 2-amino-1-methyl-6 -phenylimidazo[4,5-b]pyridine (PhIP)- induced mammary gland carcinogenesis in rats. Jpn J Cancer Res 2000, 91:886-892.

22. Russo J, Russo IH: Atlas and histologic classification of tumors of the rat mammary gland. J Mammary Gland Biol Neoplasia 2000, 5:187-200.
23. Barnes NL, Flint PJ, Knox WF, Clarke RB, Bundred NJ: Celecoxib decreases COX-2 protein expression and increases apoptosis in ductal carcinoma in situ of the breast in vivo. Meeting Abstracts: AACR 2005, 532

24. Basu GD, Pathangey LB, Tinder TL, Gendler SJ, Mukherjee P: Celecoxib, a selective COX-2 inhibitor, induces apoptosis and reduces VEGF levels in a preclinical model of metastatic breast cancer. Meeting Abstracts: AACR 2004, 317

25. Ding H, Han C, Zhu J, Chen CS, D'Ambrosio SM: Celecoxib derivatives induce apoptosis via the disruption of mitochondrial membrane potential and activation of caspase 9. Int J Cancer 2005, 113:803-810

26. Susan $L$, Sheldon M, John F, Kathleen G, Constantine D, Masferrer JL, Ben SZ, Harjeet S, Irma HR: The Cyclooxygenase-2 Inhibitor, Celecoxib, Prevents the Development of Mammary Tumors in HER-2/neu Mice. Cancer Epidemiol Biomarkers Prev 2003, 12:1486-1491.

27. Howe LR, Subbaramaiah K, Patel J, Masferrer JL, Deora A, Hudis C, Thaler HT, Muller WJ, Du B, Brown AM, Dannenberg AJ: Celecoxib, a Selective Cyclooxygenase 2 Inhibitor, Protects against Human Epidermal Growth Factor Receptor 2 (HER-2)/ neu-induced Breast Cancer. Cancer Res 2002, 62:5405-5407.

28. Rasmuson A, Kock A, Fuskevåg OM, Kruspig B, Simón-Santamaría J, Gogvadze V, Johnsen JI, Kogner P, Sveinbjörnsson B: Autocrine prostaglandin E2 signaling promotes tumor cell survival and proliferation in childhood neuroblastoma. PLoS One 2012, 7:e29331.

29. Pockaj BA, Basu GD, Pathangey LB, Gray RJ, Hernandez JL, Gendler SJ, Mukherjee P: Reduced T-cell and dendritic cell function is related to cyclooxygenase-2 overexpression and prostaglandin E2 secretion in patients with breast cancer. Ann Surg Oncol 2004, 11:328-339.

30. Tari AM, Simeone AM, Li YJ, Gutierrez-Puente Y, Lai S, Symmans WF: Cyclooxygenase-2 protein reduces tamoxifen and $\mathrm{N}$-(4-hydroxyphenyl) retinamide inhibitory effects in breast cancer cells. Lab Invest 2005, 85:1357-1367

31. Shin YK, Park JS, Kim HS, Jun HJ, Kim GE, Suh CO, Yun YS, Pyo H: Radiosensitivity enhancement by celecoxib, a cyclooxygenase (COX)-2 selective inhibitor, via COX-2-dependent cell cycle regulation on human cancer cells expressing differential COX-2 levels. Cancer Res 2005, 65:9501-9509.

32. Dvory-Sobol H, Cohen-Noyman E, Kazanov D, Figer A, Birkenfeld $S$, Madar-Shapiro L, Benamouzig R, Arber N: Celecoxib leads to G2/M arrest by induction of p21 and down-regulation of cyclin B1 expression in a p53-independent manner. Eur J Cancer 2006, 42:422-426.

33. Liu DB, Hu GY, Long GX, Qiu H, Mei Q, Hu GQ: Celecoxib induces apoptosis and cell-cycle arrest in nasopharyngeal carcinoma cell lines via inhibition of STAT3 phosphorylation. Acta Pharmacol Sin 2012, 33:682-690.

34. Márquez-Rosado L, Trejo-Solís MC, García-Cuéllar CM, Villa-Treviño S: Celecoxib, a cyclooxygenase-2 inhibitor, prevents induction of liver preneoplastic lesions in rats. J Hepatol 2005, 43:653-660.

35. Li WZ, Wang XY, Li ZG, Zhang JH, Ding YQ: Celecoxib enhances the inhibitory effect of cisplatin on Tca8113 cells in human tongue squamous cell carcinoma in vivo and in vitro. J Oral Pathol Med 2010, 39:579-584.

doi:10.1186/1475-2867-12-53

Cite this article as: Dai et al: Antitumor activity of the selective cyclooxygenase-2 inhibitor, celecoxib, on breast cancer in Vitro and in Vivo. Cancer Cell International 2012 12:53. 